Research Article

\title{
Out-of-Plane Shaking Table Tests on Seismic Response of RC Frame Infilled with a New Type of Shale Fired Heat-Insulation Blocks
}

\author{
Jian Wu $\mathbb{D}^{1},{ }^{1}$ Li-dan Zhang $\mathbb{C}^{1},{ }^{1}$ Qing Yu $\mathbb{D}^{2},{ }^{2}$ and Bo Wang $\mathbb{D}^{3}$ \\ ${ }^{1}$ Shaanxi Key Laboratory of Safety and Durability of Concrete Structures, Xijing University, Xi'an 710123, China \\ ${ }^{2}$ Anhui Provincial Architectural Design and Research Institute Co. Ltd, No. 7699 Fanhua Road, Hefei 230031, China \\ ${ }^{3}$ School of Civil Engineering, Chang'an University, Xi'an 710061, China
}

Correspondence should be addressed to Bo Wang; chnwangbo@chd.edu.cn

Received 16 June 2019; Accepted 11 June 2020; Published 31 July 2020

Academic Editor: Aniello Riccio

Copyright $\odot 2020$ Jian Wu et al. This is an open access article distributed under the Creative Commons Attribution License, which permits unrestricted use, distribution, and reproduction in any medium, provided the original work is properly cited.

Shale fired heat-insulation block, which is made of shale, fly ash, building rubbish, and waste paper, is a new type environmentfriendly product. In order to study the mechanical properties of shale fired heat-insulation block walls, four full-scale walls were tested under El-Centro, Taft, and Ninghe earthquakes using shaking table equipment, in which the influence of the spacing of castin-place belt and the connection between the wall and the frame on the out-of-plane seismic performance of the wall was taken into account. The subject of this study is mainly about out-of-plane dynamic response of masonry walls in terms of frequency, displacement, and acceleration. It could be concluded that the cast-in-place belt and the rigid connection between wall and RC frame could effectively reduce the out-of-plane seismic response of the infill masonry wall. Finally, the recommendations for the use of this type of block in the structure are given.

\section{Introduction}

Masonry walls, whether in traditional rural masonry structures or urban high-rise buildings, are widely used. The effect of earthquake should be considered in the process of structural design in most areas of China [1]. Especially on May 12, 2008, the Wenchuan earthquake led to the collapse of about 6,945,000 buildings [2]. Most of the buildings that collapsed or seriously damaged could be considered as brick masonry construction [3]. So in order to provide the basis for the analysis of monolithic structure, it is necessary to study the mechanical performance of the masonry walls subjected to earthquakes.

Because of economic factor, unreinforced masonry walls are still used in some regions of low to moderate seismicity. Salmanpour et al. [4] introduced the effects of various factors on the displacement capacity of unreinforced walls, i.e., unit type, vertical precompression level, aspect ratio, size, and boundary conditions. Snoj and Dolšek [5] gave the fragility functions of unreinforced masonry walls built from hollow clay units. Sajid et al. [6] investigated the effect of vertical stresses and flanges on the lateral in-plane response of the unreinforced brick masonry walls, and it could be concluded that the two factors significantly improved seismic response of URBM walls. Rosti et al. [7] studied the seismic performance of unreinforced masonry concrete blocks, and the analytical method was used to verify the test results. But in practical engineering, reinforced masonry wall is more widely used, and there is a lot of research on testing the seismic response of reinforced masonry walls.

The in-plane mechanical properties of steel frames or concrete frames infilled with masonry can be found in the literature [8-13], and unreinforced masonry walls, being reinforced by steel frames or concrete frames, could also be strengthened with other methods [14-18]. A substantial amount of research studies on the analysis model of masonry walls has been invested on the response of the masonry walls [19-23]. Besides the in-plane performance, masonry walls 
often suffer from out-of-plane damage in earthquakes, as shown in Figure 1, so the out-of-plane performance of masonry walls is also common in the existing literature. Kariou et al. [24] investigated the out-of-plane response of masonry walls strengthened with textile-reinforced mortar (TRM), and the results suggested that TRM significantly increased the load-bearing capacity of masonry walls. Anil et al. [25] studied the out-of-plane behavior of walls strengthened by CFRP materials, and it could be observed that the applied strengthening method improved the performance of masonry infill walls against out-of-plane forces. Sokairge et al. [26] investigated the behavior of PT drystacked interlocking masonry (DSIM) walls under out-ofplane loading. Compared with conventionally reinforced walls, this method could achieve a remarkable increase in the cracking load triple, in addition to improving the durability and enhancing the appearance. Shermi and Dubey [27] used welded wired mesh (WWM) to strengthen the masonry, and the results show that WWM could enhance the flexural strength and ductility of masonry. Some researchers also used shaking table tests to study the out-of-plane performance of masonry walls. Nezhad et al. [28] described an experimental procedure of three "I" shaped half-scale bearing masonry walls, which were strengthened by fiberreinforced composites. The results revealed that FRP reinforcement could improve the out-of-plane performance of masonry walls. Paton-Cole et al. [29] summarized the results of the shaking table test conducted on a full-scale steelframed brick veneer house, which exhibit good performance under serviceability and ultimate conditions in New Zealand. Graziotti et al. [30] studied the performance of four full-scale single leaf and one full-scale cavity URM walls through dynamic tests, and the results show that despite sustaining accelerations of $1.0 \mathrm{~g}$ without any damage, the specimens exhibited a rather brittle response.

The block used in this paper is made of shale, fly ash, crushed bricks, and pore-inducing materials, which could minimize the harm to the environment, as given in Figure 2. The heat transfer coefficient of shale fired heat-insulation block wall is $0.727 \mathrm{~W} /\left(\mathrm{m}^{2} \cdot \mathrm{K}\right)$, which is much lower than that of the fired common brick [31]. Considering that the compressive strength of shale fired heat-insulation block and the in-plane performance of masonry walls have been studied [31], this paper mainly investigates the out-of-plane seismic performance of masonry walls strengthened with RC frames. Compared with cyclic loading tests, shaking table tests could reflect the response of the masonry wall under the actual earthquake, so the tests are carried out on a shaking table using seismic waves corresponding to the seismic characteristics of the location of the research project. In order to study the role of the spacing of cast-in-place belt and connection modes between the infill wall and frame, four full-scale single-layer single-span infilled frame specimens are designed through the orthogonal test.

\section{Experimental Program}

2.1. Specimen Design. The block used in this study is produced in Xinjiang province, China. The dimensions of the block are shown in Figure 3. The void ratio is 54\%. The main components of the mortar are cement and chemical additives, which could guarantee the bonding strength when the thickness is relatively thin $(1 \mathrm{~mm} \sim 2 \mathrm{~mm})$. The compressive strength of the block and mortar are 11.4 MPa and 17.5 MPa, respectively.

Orthogonal experiment is an effective method to solve multifactor test problems. The factors that affect the test indicators are called experimental factors, generally indicated by A, B, C, etc. The state or condition of the change of the factor is called the level of the test factor, generally indicated by 1,2 , 3 , etc. In this paper, the orthogonal experiments are designed as three factors and two levels, including the connection between the infilled wall and the frame and cast-in-place belt spacing, which demonstrate the out-of-plane seismic response of the masonry walls, as shown in Table 1.

Based on Table 1, four full-scale single-layer single-span infilled frame specimens are built. Number and type of the specimens are given in Table 2.

In Figure 4, the "W" indicates "Wall." The gap is filled with mortar or polyurethane foaming agent, so as to reflect the connection condition between the infill wall and frame. The cast-in-place belt is designed to improve the mechanical performance of the wall. The strain gauge, acceleration sensor, and displacement sensor are used to measure the strain of steel bar, acceleration, and displacement of the specimens, the location of which are shown in Figure 4.

2.2. Material Properties. The steel reinforcement and concrete used in each component in the masonry wall are shown in Table 3, and the reinforcement drawing is given in Figure 5. The mechanical properties of the steel reinforcement could be seen in Table 4 .

2.3. Loading Procedure. The shaking table can simulate earthquake wave up to $50 \mathrm{~Hz}$, with $1.5 \mathrm{~g}$ acceleration in $x$ direction and $1.0 \mathrm{~g}$ acceleration in $y$ and $z$ directions. The table with $4.1 \mathrm{~m} \times 4.1 \mathrm{~m}$ dimension is characterized by three degrees of freedom, as shown in Figure 6. According to the seismic requirements of the area where the block is used, ElCentro, Taft, and Ninghe records are chosen to investigate the out-of-plane seismic performance of masonry walls, as shown in Figure 7. The scheme of the loading test is given in Table 5. In this table, PGA is the peak ground acceleration and $g$ is the acceleration of gravity. According to different loading steps, the acceleration amplitude of El-Centro wave is adjusted on the basis of the peak value of acceleration of earthquake. White noise is used to scan the frequency of the wall.

\section{Experimental Results and Discussion}

3.1. Experimental Phenomena. In general, cracks mainly appeared at the bottom of the wall when the test was finished, as illustrated in Figure 8. When the peak acceleration was $0.5 \mathrm{~g}$ or $0.6 \mathrm{~g}$, cracks first appeared at the bottom of the columns or wall. When the input acceleration continued to 


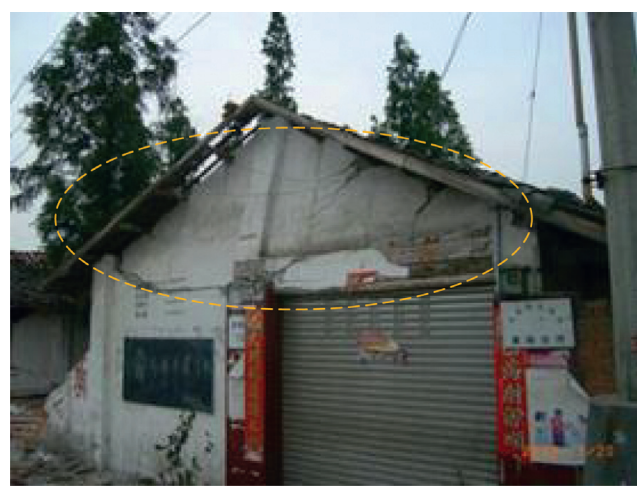

(a)

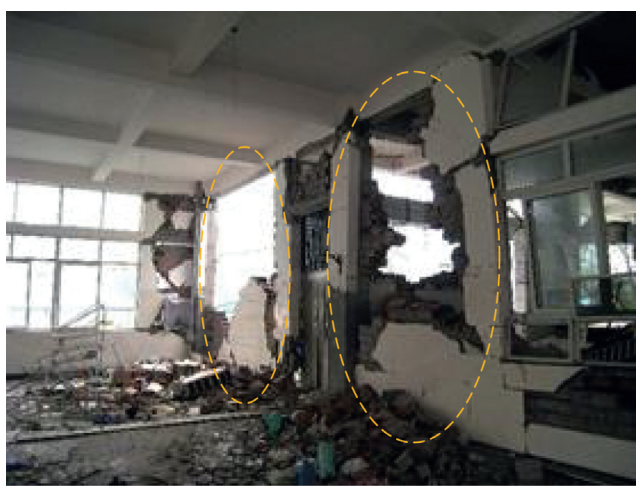

(b)

FIGURE 1: Out-of-plane failure of walls (Wenchuan earthquake, May 12, 2008).
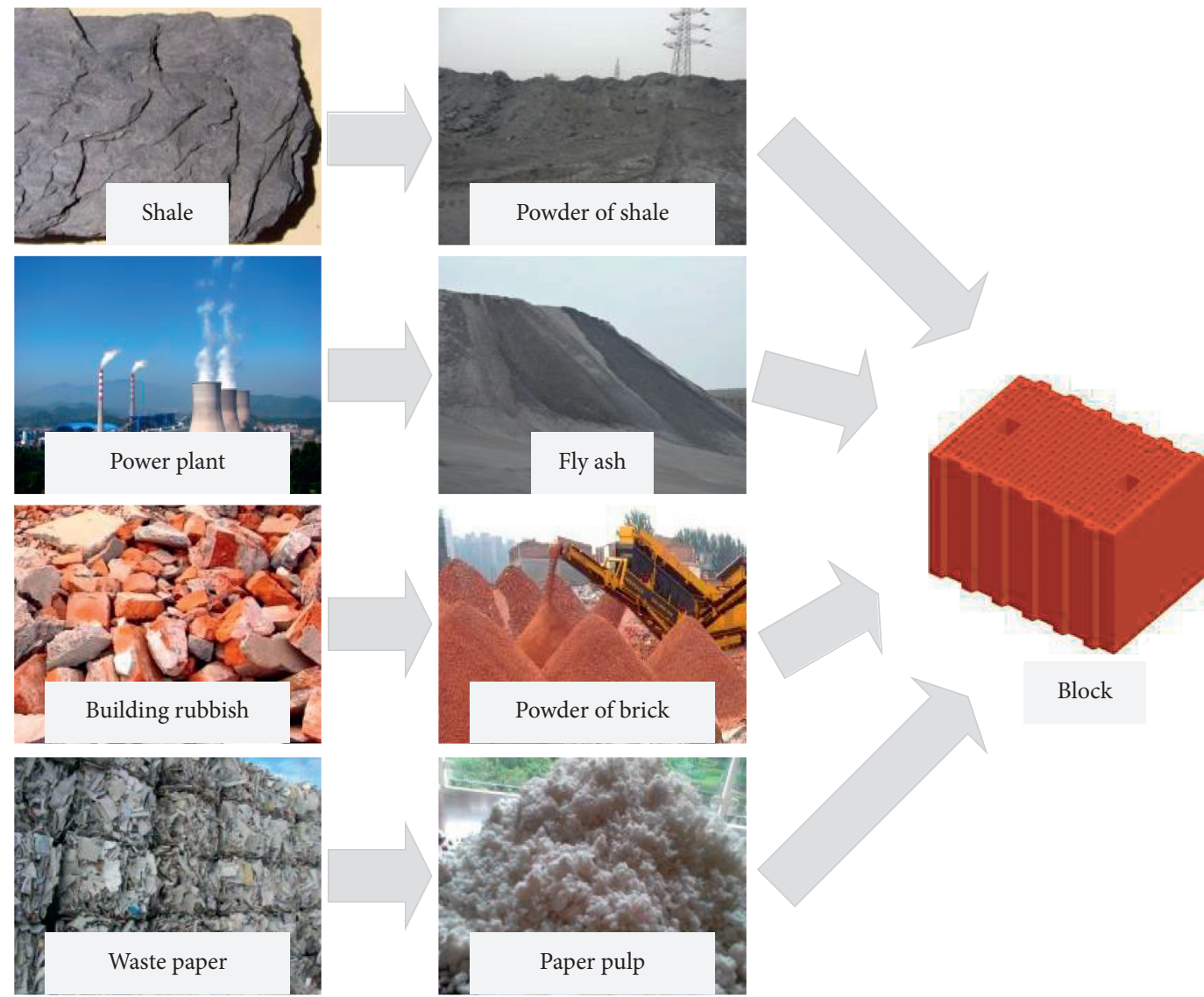

Block

FIgURE 2: Raw materials of the block.

increase, more cracks appeared at the bottom, and some cracks joined together when the walls were broken. For W-2 and $\mathrm{W}-3$, cracks basically penetrated the bottom of the wall at the end of the experiment, while for $\mathrm{W}-1$ and $\mathrm{W}-4$, the bottom cracks did not penetrate the wall completely. There were a small number of fine cracks in the upper part of the four walls, while the damage degrees of walls were not particularly serious.

Comparing the failure phenomena of four specimens, the damage of $\mathrm{W}-4$ is slightest, while the damage of $\mathrm{W}-2$ is most serious, which show that different measures have a great influence on the out-of-plane seismic response of the infill wall.

3.2. Natural Frequency of the Wall. Through white noise scanning, variation of natural frequencies of specimens can be seen in Figure 9. It could be found that after the first four white noise scanning, the frequency changes of specimens are very small. When the 6th white noise scanning is carried out, the frequency of the specimens decreases greatly, which indicates that the damage of the wall is greater and the stiffness is significantly reduced. 


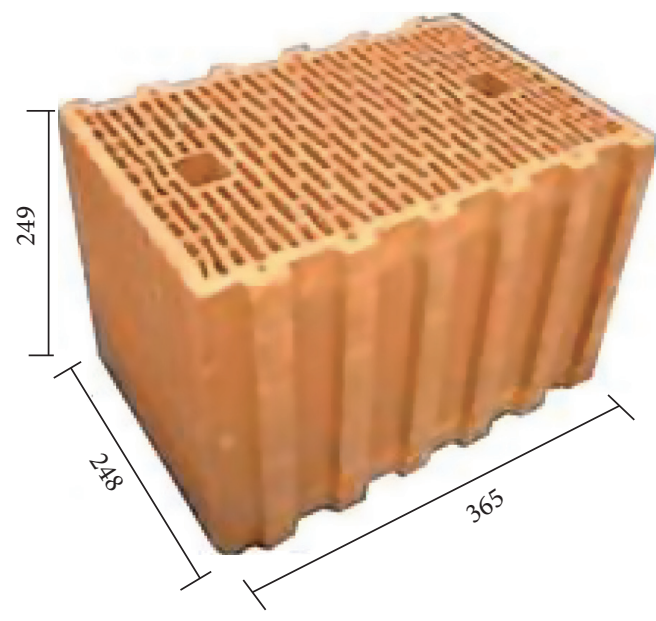

(a)

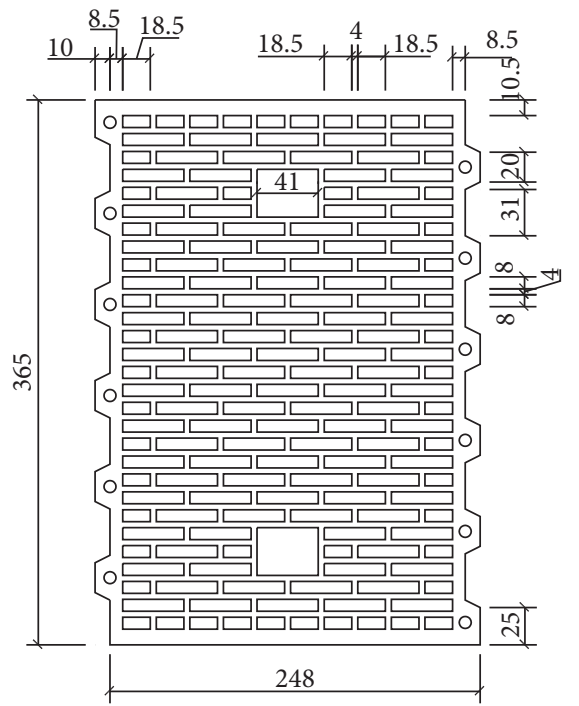

(b)

Figure 3: Fired shale heat-insulation block (mm). (a) External dimensions. (b) Hole dimensions.

TABle 1: Orthogonal experiment list.

\begin{tabular}{|c|c|c|c|}
\hline \multirow[b]{2}{*}{ Levels } & \multicolumn{3}{|c|}{ Experimental factors } \\
\hline & $\begin{array}{l}\text { A } \\
\begin{array}{c}\text { The connection of infilled wall with } \\
\text { column }\end{array}\end{array}$ & $\begin{array}{c}\text { B } \\
\text { Spacing of cast-in-place belt } \\
(\mathrm{mm})\end{array}$ & $\begin{array}{c}\text { C } \\
\text { The connection of infilled wall with beam }\end{array}$ \\
\hline 1 & $\begin{array}{c}\text { Infilled wall and columns are connected } \\
\text { by mortar }\end{array}$ & 1250 & $\begin{array}{l}\text { Infilled wall and beam are connected by steel bar, being } \\
\text { filled with mortar }\end{array}$ \\
\hline 2 & $\begin{array}{l}\text { Infilled wall and column are not } \\
\text { connected }\end{array}$ & 750 & Infilled wall and beam are connected by steel bar \\
\hline
\end{tabular}

TABLE 2: Types of masonry wall.

Number The connection of infilled wall with column Spacing of cast-in-place belt $(\mathrm{mm})$ The connection of infilled wall with beam

\begin{tabular}{|c|c|c|c|}
\hline $\mathrm{W}-1$ & Unconnected & 1250 & Connected by steel bar and mortar \\
\hline W-2 & Connected by mortar & 1250 & Connected by steel bar \\
\hline $\mathrm{W}-3$ & Unconnected & 750 & Connected by steel bar \\
\hline $\mathrm{W}-4$ & Connected by mortar & 750 & Connected by steel bar and mortar \\
\hline
\end{tabular}

The decrease rates of natural frequencies of $\mathrm{W}-1 \sim \mathrm{W}-4$ are $11.29 \%, 16.61 \%, 15.49 \%$, and $9.96 \%$, respectively, which show that the connection between infilled walls and frame beams has a great influence on the stiffness degradation of specimens. This is because when the wall begins to break down, due to the tight connection at the top of the wall, the arch bearing mechanism plays a role in improving the outof-plane bearing capacity of the masonry wall [32].

3.3. Analysis of Wall Acceleration Response. The maximum acceleration of the wall generally appears at the top of the wall, as shown in Figure 10. At the initial stage of loading, the specimen is basically in the elastic state, so the acceleration of the specimen increases with the increasing of peak input acceleration. With the process of experiments, different degrees of damage will occur inside and outside the wall, resulting in the continuous reduction of stiffness and an increase in damping, so the acceleration amplification coefficient of specimen decreases. However, when the failure occurred to a certain extent, the acceleration amplification coefficient of the specimen increased again until the specimen is further damaged (the middle part of $\mathrm{W}-1 \sim \mathrm{W}-4$, the upper part of $\mathrm{W}-1$ and $\mathrm{W}-2$ ).

At the same time, it could be found from Figure 10 that comparing with connection between infilled wall and column, the connection between infilled wall and beam can improve the out-of-plane seismic performance more effective, and also, a smaller cast-in-place spacing can enhance the out-of-plane mechanical properties of the wall. 

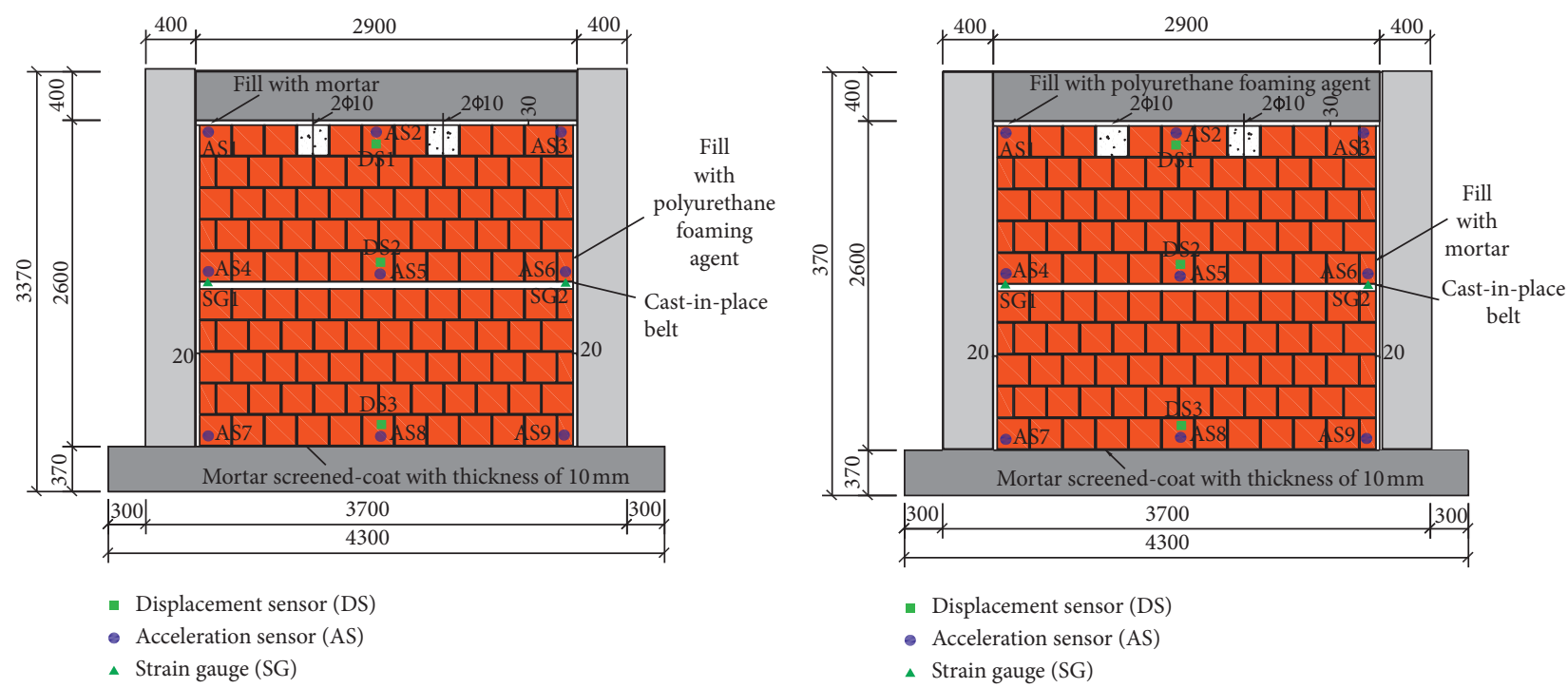

(a)

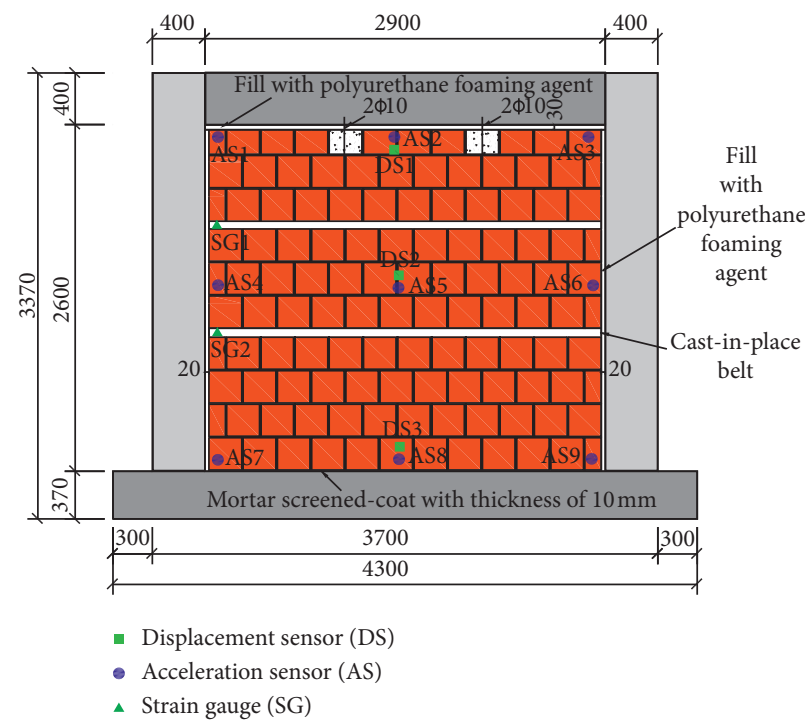

(c)

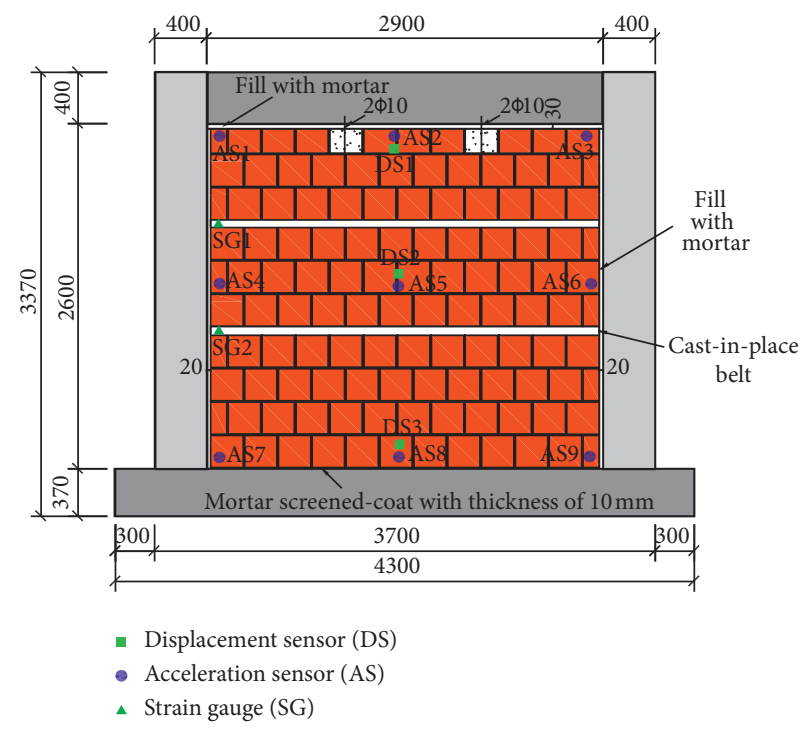

(d)

Figure 4: Design of specimens (mm) and instrumentation arrangement. (a) W-1. (b) W-2. (c) W-3. (d) W-4.

TABLE 3: Type of materials.

\begin{tabular}{lccc}
\hline Component & Longitudinal reinforcement & Stirrup & Concrete strength (MPa) \\
\hline Beam & C20, C22 & A10 & 35.2 \\
Column & C20 & A10 & 35.2 \\
Cast-in-place belt & A10 & A6 & 21.3 \\
\hline
\end{tabular}

3.4. Analysis of Wall Displacement Analysis. Relative displacement of different positions of walls is given in Figure 11. The relative displacement refers to the difference between the displacement of the specimen and the ground beam. Because the displacement of the lower part of the wall is basically the same as that of the ground beam, only the relative displacement of the upper and middle part of the wall is given in Figure 11.

With the increasing of peak input acceleration, the relative displacement of the specimens increases gradually, and the relative displacement along the height direction is also increasing. Compared with the other specimens, W-3 has larger maximum relative displacement. When the input acceleration of the shaking table is $0.8 \mathrm{~g}$, the maximum relative displacement of $\mathrm{W}-3$ increases rapidly, meaning that the seismic response of $\mathrm{W}-3$ is intensified and its deformation ability is strong.

The interstory displacement angle of the wall under common earthquake intensity is shown in Table 6 . According to the requirements of Chinese code [1], the limit 


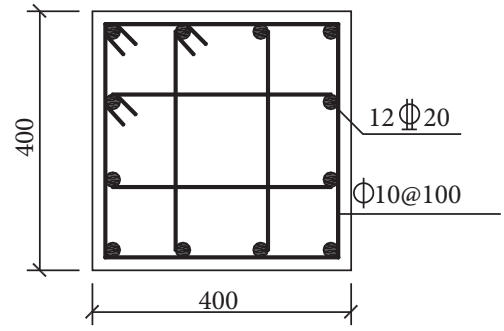

(a)

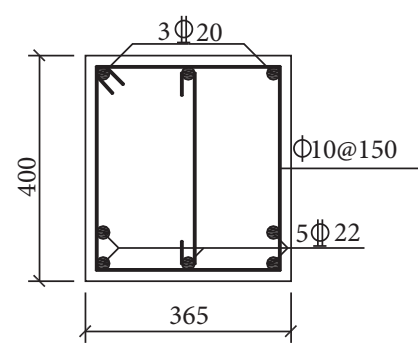

(b)

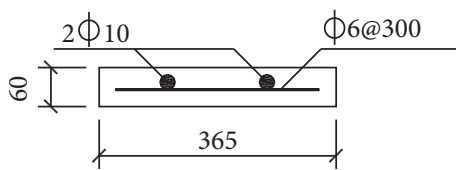

(c)

Figure 5: Reinforcement drawing. (a) Column. (b) Beam. (c) Cast-in-place belt.

TABLE 4: Strength of steel bar.

\begin{tabular}{lccccc}
\hline Type & Diameter $(\mathrm{mm})$ & Yield strength $(\mathrm{MPa})$ & Ultimate strength $(\mathrm{MPa})$ & Elastic modulus $(\mathrm{MPa})$ & Yield strain $\left(10^{-6}\right)$ \\
\hline A6 & 6.0 & 276 & 475 & $2.1 \times 10^{5}$ & 1314 \\
A10 & 10.0 & 283 & 484 & $2.0 \times 10^{5}$ & 1415 \\
C20 & 20.0 & 415 & 560 & $2.0 \times 10^{5}$ & 2075 \\
\hline
\end{tabular}

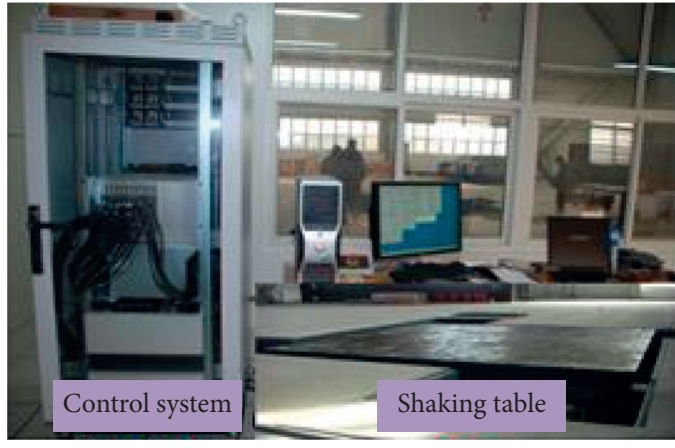

(a)

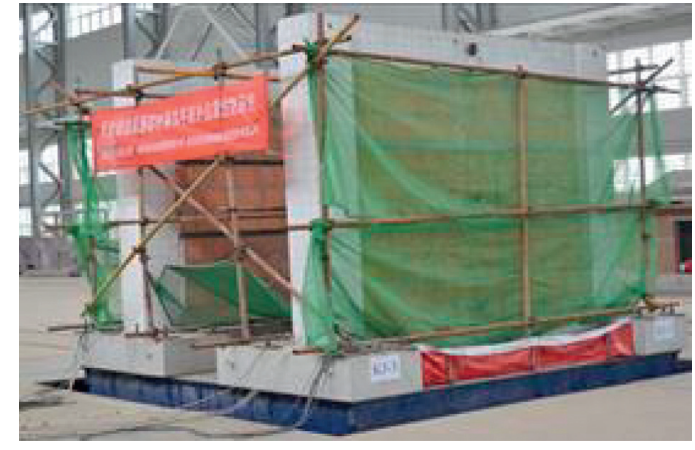

(b)

FIGURE 6: Shaking table system and specimen. (a) Shaking table system. (b) Specimen.

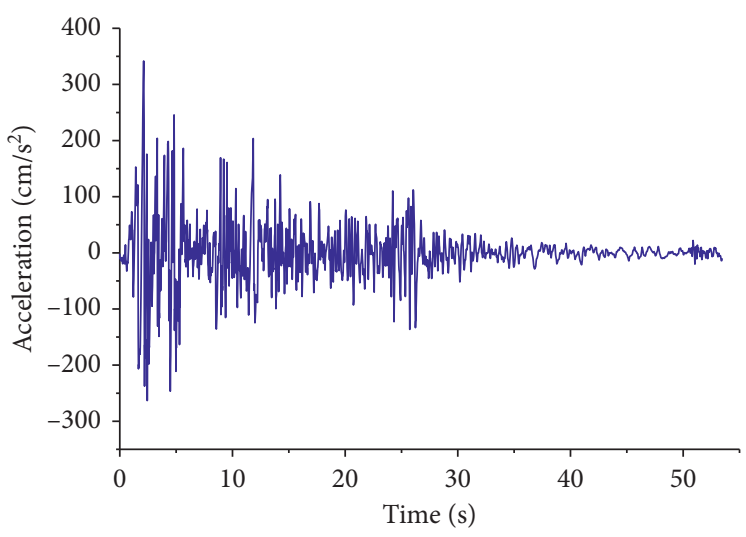

(a)

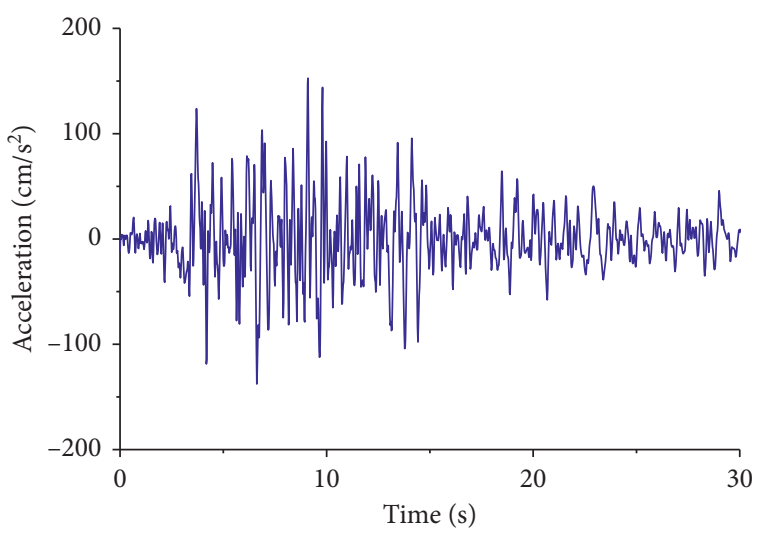

(b)

FIgURE 7: Continued. 


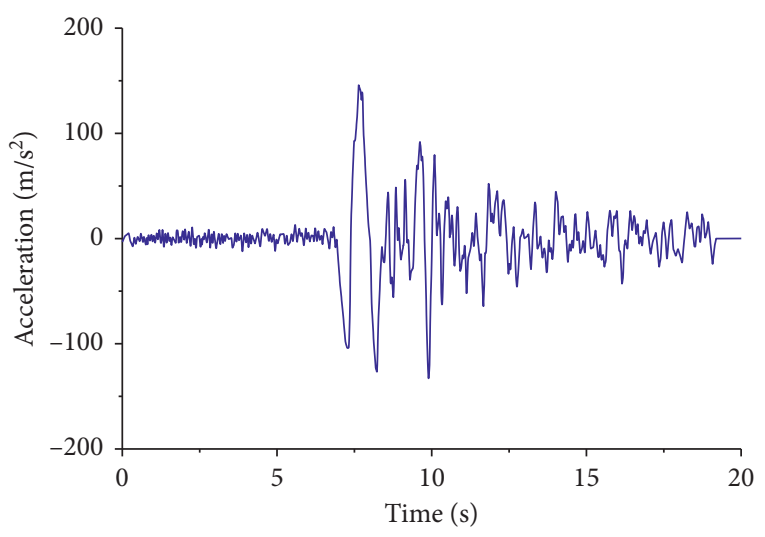

(c)

Figure 7: Acceleration time history curves of earthquakes. (a) El-Centro record. (b) Taft record. (c) Ninghe record.

TABLE 5: Loading procedure.

\begin{tabular}{lcccccccc}
\hline Number & Loading condition & PGA & Number & Loading condition & PGA & Number & Loading condition & PGA (g) \\
\hline 1 & White noise & 0.05 & 8 & Ninghe wave & 0.10 & 15 & El-Centro wave & 0.50 \\
2 & El-Centro wave & 0.05 & 9 & White noise & 0.05 & 16 & White noise & 0.05 \\
3 & Taft wave & 0.05 & 10 & El-Centro wave & 0.15 & 17 & El-Centro wave & 0.60 \\
4 & Ninghe wave & 0.05 & 11 & El-Centro wave & 0.20 & 18 & El-Centro wave & 0.70 \\
5 & White noise & 0.05 & 12 & White noise & 0.05 & 19 & El-Centro wave & 0.80 \\
6 & El-Centro wave & 0.10 & 13 & El-Centro wave & 0.30 & 20 & El-Centro wave & 0.90 \\
7 & Taft wave & 0.10 & 14 & El-Centro wave & 0.40 & 21 & White noise & 0.05 \\
\hline
\end{tabular}

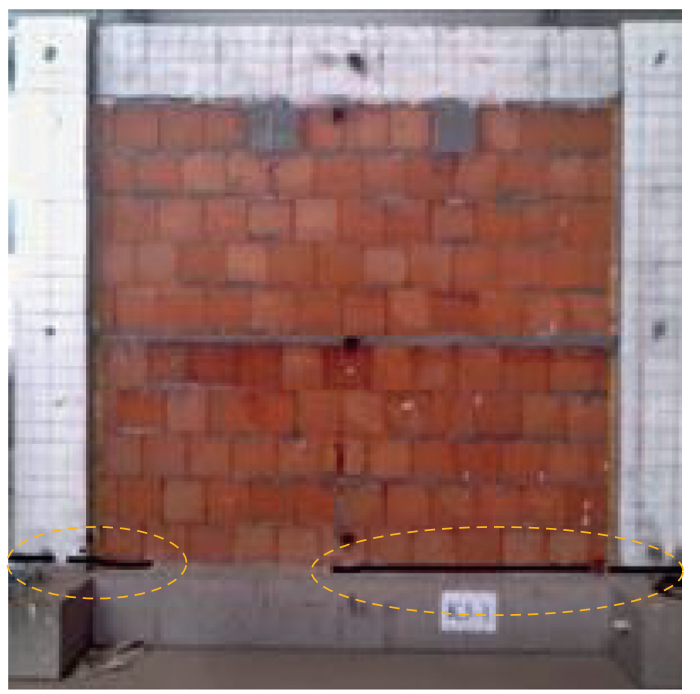

(a)

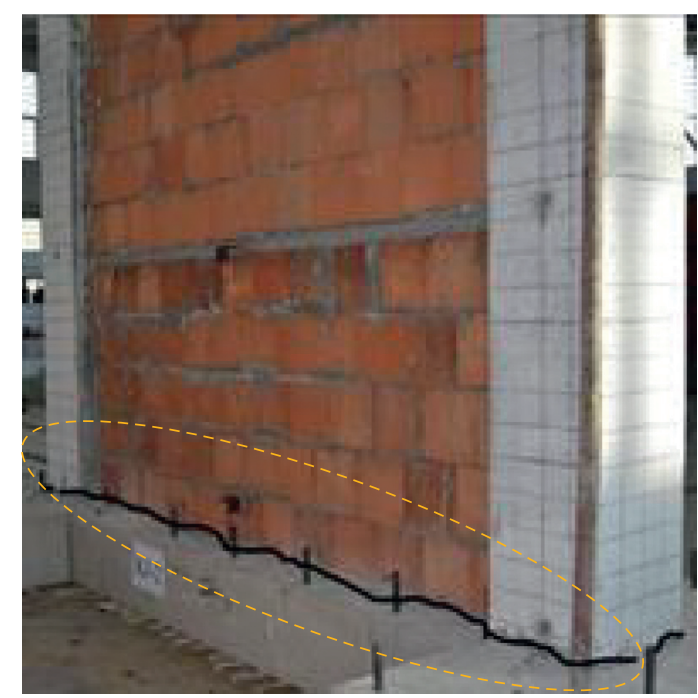

(b)

FIgURE 8: Continued. 


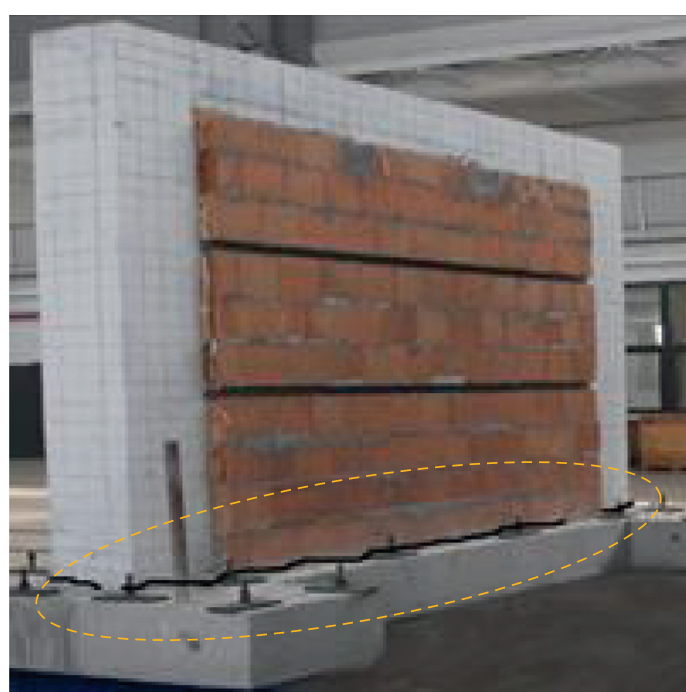

(c)

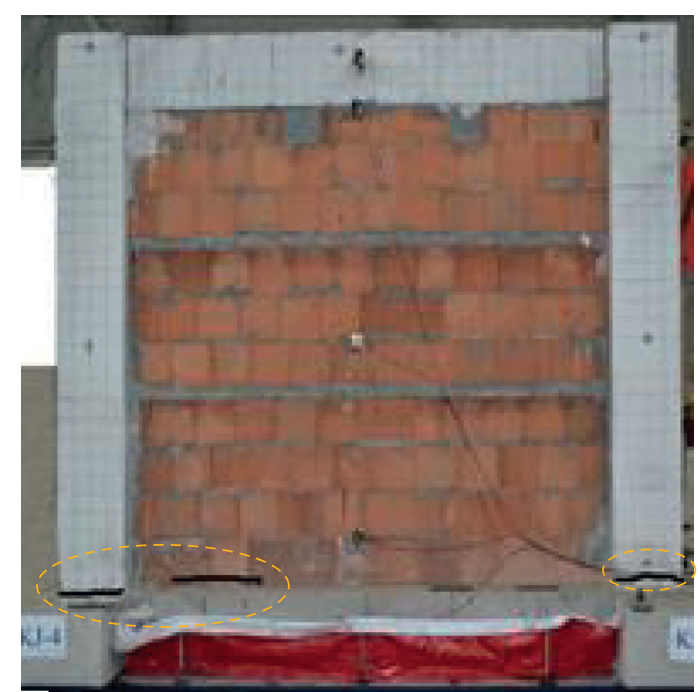

(d)

Figure 8: Condition of walls at the conclusion of testing. (a) W-1. (b) W-2. (c) W-3. (d) W-4.

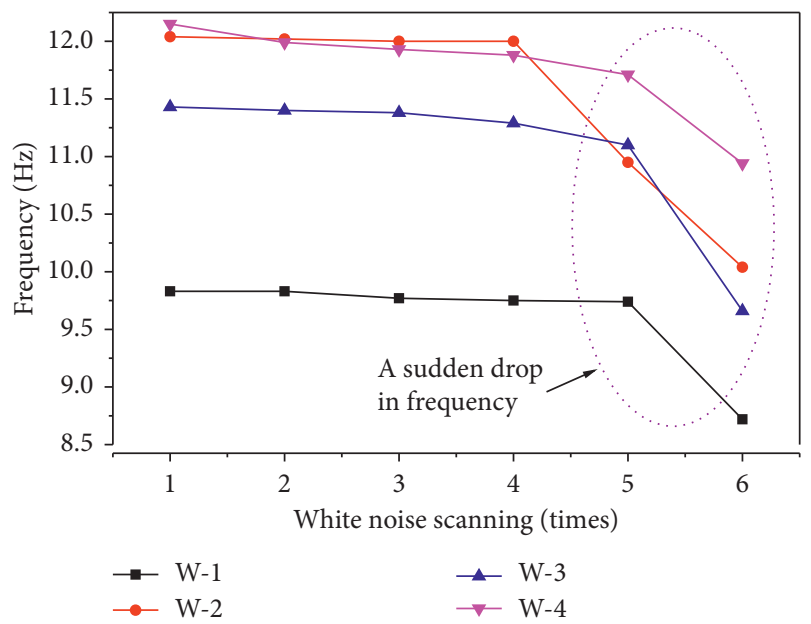

FIGURE 9: Natural frequency of the wall.

values of elastic interstory displacement angle under frequent earthquake is $1 / 550$ and elastic-plastic interstory displacement angle under rare earthquake is $1 / 50$ in the area where the block is used. For frequent earthquake, the peak input acceleration is established as $0.07 \mathrm{~g}$ and $0.11 \mathrm{~g}$, respectively, while the peak acceleration of rare earthquake are $0.40 \mathrm{~g}$ and $0.50 \mathrm{~g}$ [1]. Because of the setting of the loading steps in this test, the peak acceleration of frequent earthquake is replaced by $0.10 \mathrm{~g}$ and $0.15 \mathrm{~g}$, respectively, which can guarantee the reliability of the results. All the walls can meet the norms, showing that reinforcement measures could improve the out-of-plane deformation performance of walls.

3.5. Strain Analysis of Steel Bar. The maximum strain of the steel bar in the cast-in-place belt measured at different positions is described in Figure 12. Note that if the gap between the wall and the beam is filled with mortar (W-1 and $\mathrm{W}-4$ ), the stress of the cast-in-belt can be effectively reduced, indicating that connection between the wall and beam can improve the out-of-plane mechanical performance of the specimen.

It can be drawn that the maximum strains of $\mathrm{W}-1 \sim \mathrm{W}-4$ are $32.47 \times 10^{-6}, 46.31 \times 10^{-6}, \quad 296.46 \times 10^{-6}$, and $93.27 \times 10^{-6}$, respectively. The stress of reinforcing bar could be calculated according to Hooke's law:

$$
\sigma=E \varepsilon
$$

where $E$ is the elastic modulus and $\varepsilon$ is the strain.

It could be obtained that the maximum stress of the steel bar is $59.29 \mathrm{MPa}$, which is much smaller than the yield strength, showing that the performance of cast-in-place belt is reliable.

3.6. Analysis of Orthogonal Test. According to seismic requirements for buildings in China, this paper mainly studies the response of relative displacement and acceleration amplification coefficient of walls under different input accelerations, and then the orthogonal experiment method is used to analyze the test results, as shown in Tables 7 and 8 . Here, $x_{i}$ is calculated through the synthetic weighted mark method [33], I and II are the estimates of the horizontal effects of 1 and 2 on each corresponding column (factor), $K_{1}$ and $K_{2}$ are the comprehensive average value of level 1 and level 2 , and $R$ is range.

When the input acceleration is $0.9 \mathrm{~g}$, the relative displacement of $\mathrm{W}-3$ has a sudden increase, meaning that the specimen has been damaged, so the value of this column is rounded off. From Tables 7 and 8 and Figure 13, it could be concluded as follows:

(1) According to the magnitude of $R$, the important order of the factors is $B \longrightarrow C \longrightarrow A$, showing that the spacing of cast-in-place belt has the greatest 


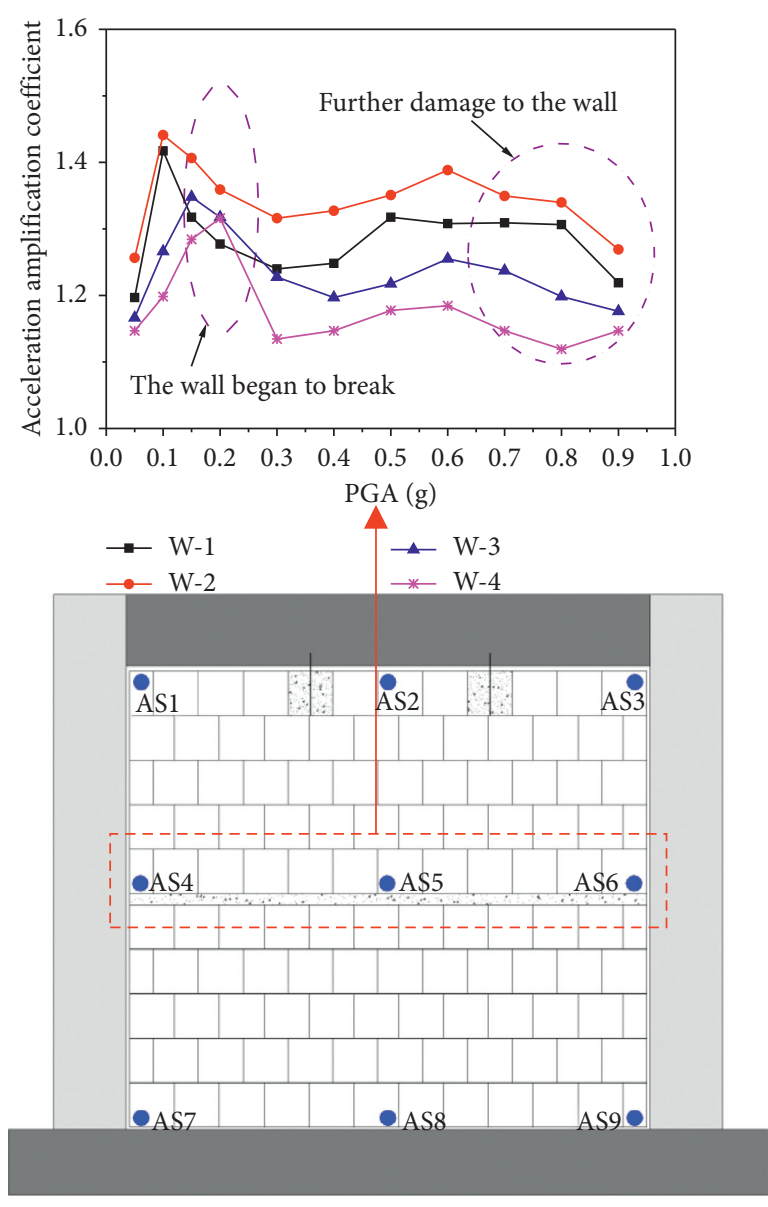

(a)
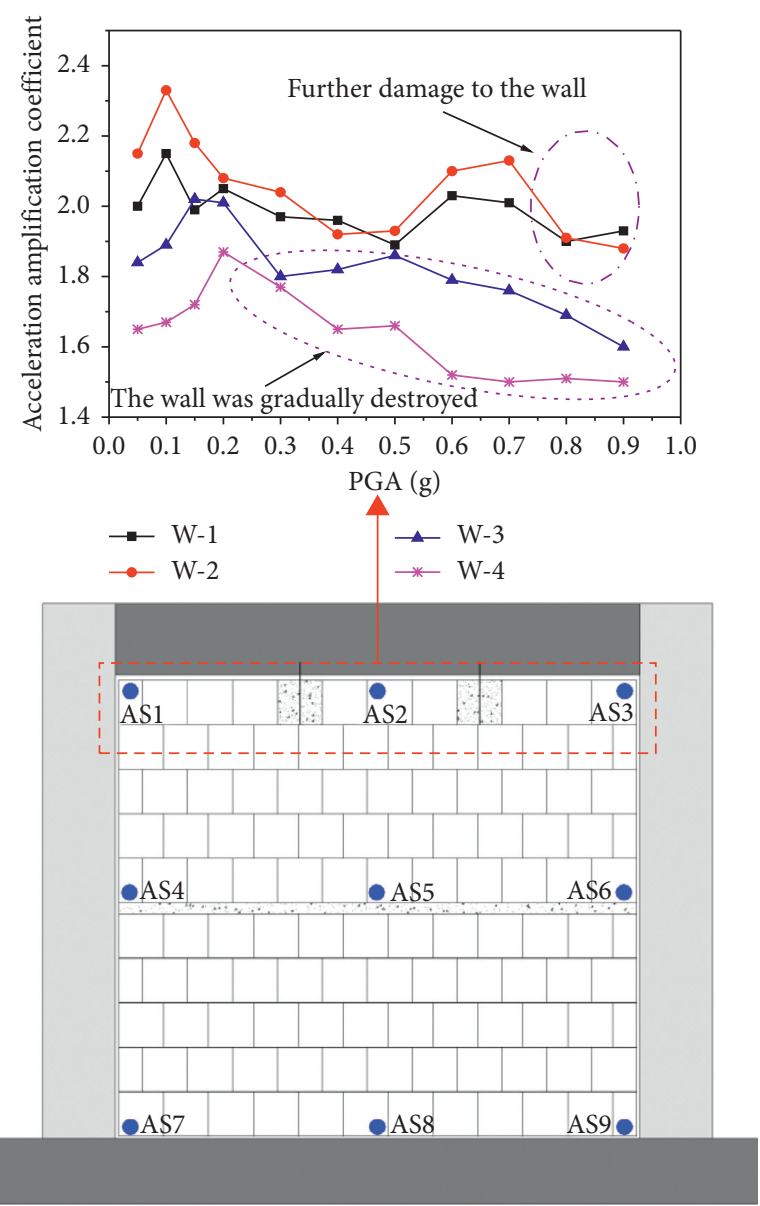

(b)

FIGURE 10: Acceleration amplification coefficient of the wall. (a) In the middle of the wall. (b) At the top of the wall.

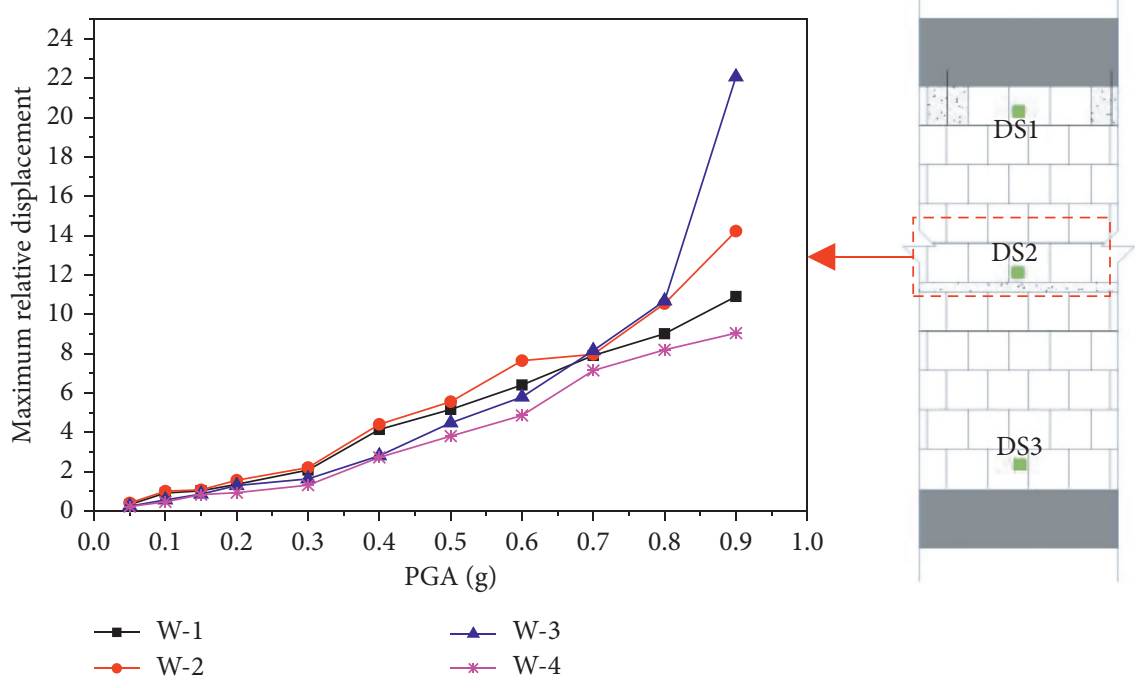

(a)

FIgURe 11: Continued. 


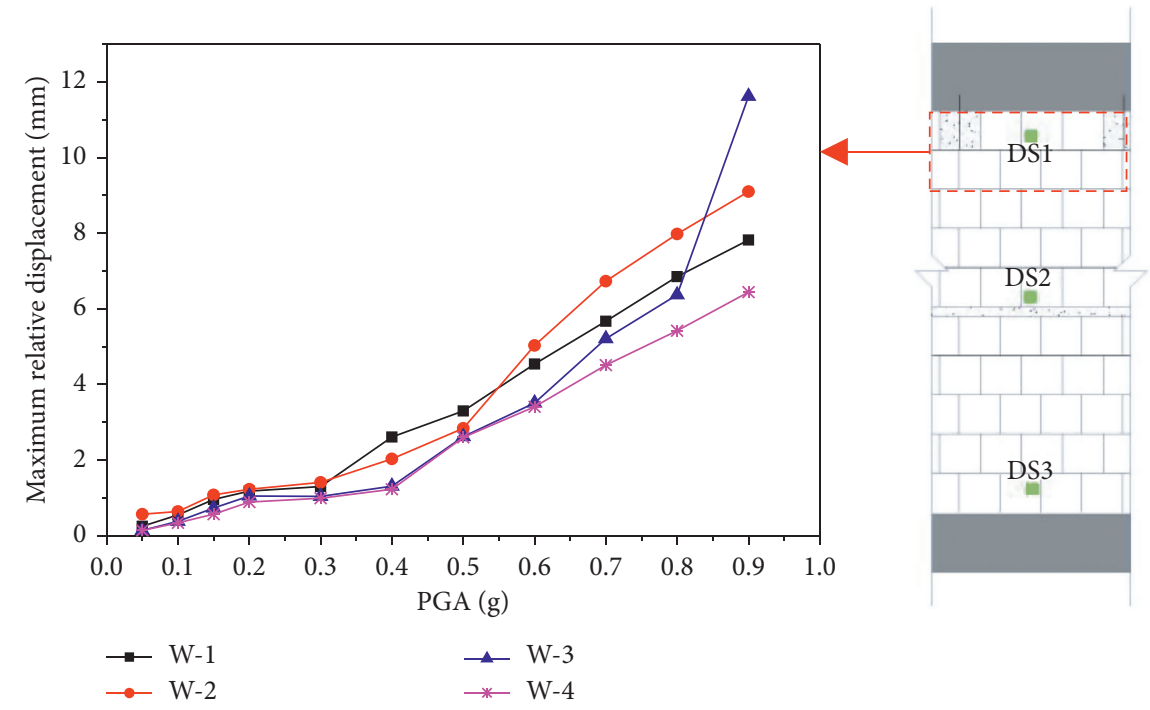

(b)

FIGURE 11: Relative displacement of the wall. (a) In the middle of the wall. (b) At the top of the wall.

TABLE 6: Interstory displacement angle.

\begin{tabular}{lcccc}
\hline Number & \multicolumn{2}{c}{$\begin{array}{c}\text { Interstory displacement angle of } \\
\text { frequent earthquake }\end{array}$} & \multicolumn{2}{c}{$\begin{array}{c}\text { Interstory displacement angle of rare } \\
\text { earthquake }\end{array}$} \\
\hline $\mathrm{W}-1$ & $0.10 \mathrm{~g}$ & $0.15 \mathrm{~g}$ & $0.40 \mathrm{~g}$ & $0.50 \mathrm{~g}$ \\
$\mathrm{~W}-2$ & $1 / 3261$ & $1 / 2913$ & $1 / 723$ & $1 / 580$ \\
$\mathrm{~W}-3$ & $1 / 2970$ & $1 / 2778$ & $1 / 680$ & $1 / 540$ \\
$\mathrm{~W}-4$ & $1 / 5263$ & $1 / 3488$ & $1 / 1068$ & $1 / 668$ \\
\hline
\end{tabular}

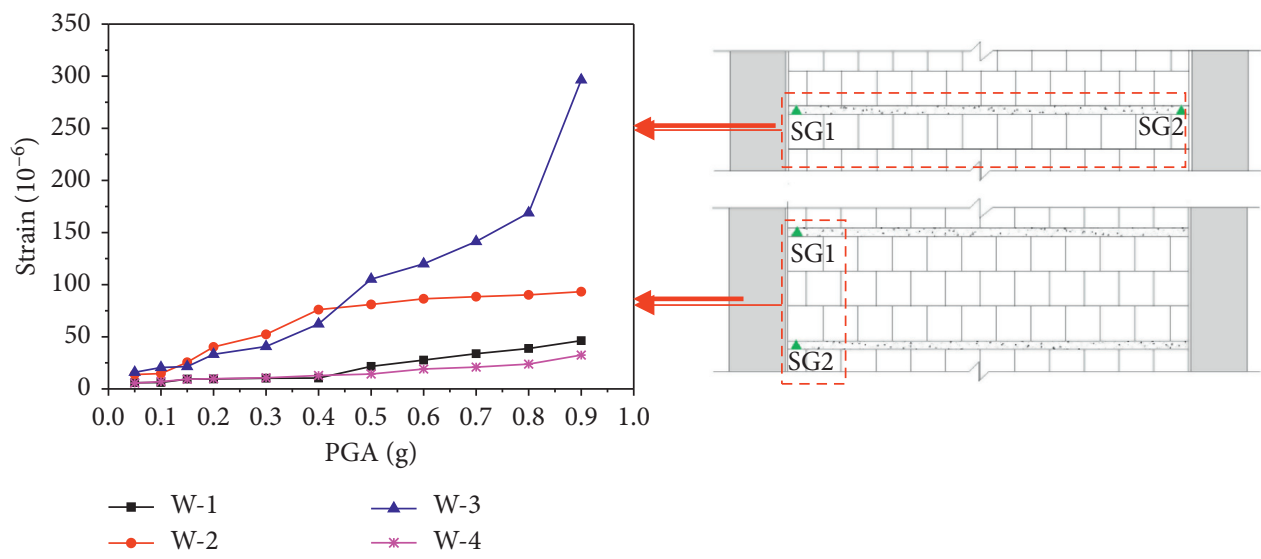

FIGURE 12: Strain of steel bar in the cast-in-place belt.

influence, followed by the connection mode between walls and frame beams, and the connection mode between walls and frame columns has the least influence.

(2) The strongest and weakest combinations are determined based on the primary and secondary conditions of the factors and their respective horizontal displacements and acceleration amplification coefficient. The strongest combination is $\mathrm{A} 1 \mathrm{~B} 2 \mathrm{C} 1$ (connection between the wall and constraining frame is rigid, and the cast-in-place belt spacing is $750 \mathrm{~mm}$ ), and the weakest combination is A2B1C2 (connection between the wall and constraining frame is flexible, and spacing of the cast-in-place belt is $1250 \mathrm{~mm}$ ).

\section{Recommendations}

The three-dimensional model of the specimen is shown in Figure 14. Based on the experimental results and 
TABle 7: Analysis of result of displacement at the top of the wall.

\begin{tabular}{|c|c|c|c|c|c|c|c|c|c|c|c|c|c|c|}
\hline \multirow{2}{*}{ Specimen } & \multicolumn{3}{|c|}{ Test factors } & \multicolumn{11}{|c|}{ Displacement at top of the wall $(\mathrm{mm})$} \\
\hline & $A$ & $B$ & $C$ & $0.05 \mathrm{~g}$ & $0.1 \mathrm{~g}$ & $0.15 \mathrm{~g}$ & $0.2 \mathrm{~g}$ & $0.3 \mathrm{~g}$ & $0.4 \mathrm{~g}$ & $0.5 \mathrm{~g}$ & $0.6 \mathrm{~g}$ & $0.7 \mathrm{~g}$ & $0.8 \mathrm{~g}$ & $x_{i}$ \\
\hline $\mathrm{W}-1$ & 2 & 1 & 1 & 0.33 & 0.92 & 1.03 & 1.36 & 2.09 & 4.15 & 5.17 & 6.41 & 7.91 & 9.02 & 38.40 \\
\hline $\mathrm{W}-2$ & 1 & 1 & 2 & 0.41 & 1.01 & 1.08 & 1.57 & 2.21 & 4.41 & 5.56 & 7.65 & 7.97 & 10.55 & 42.42 \\
\hline $\mathrm{W}-3$ & 2 & 2 & 2 & 0.25 & 0.57 & 0.86 & 1.30 & 1.64 & 2.81 & 4.49 & 5.80 & 8.16 & 10.69 & 36.57 \\
\hline W-4 & 1 & 2 & 1 & 0.23 & 0.47 & 0.84 & 0.94 & 1.32 & 2.73 & 3.81 & 4.86 & 7.15 & 8.20 & 30.56 \\
\hline I & 80.82 & 74.97 & 78.99 & & & & & & & & & & & \\
\hline II & 67.13 & 72.98 & 68.96 & & & & & & & & & & & \\
\hline$K_{1}$ & 40.41 & 37.49 & 39.50 & & & & & & & & & & & \\
\hline$K_{2}$ & 33.57 & 36.49 & 34.48 & & & & & & & & & & & \\
\hline$R$ & 6.84 & 1.00 & 5.02 & & & & & & & & & & & \\
\hline
\end{tabular}

Table 8: Analysis of result of acceleration amplification coefficient at the top of the wall.

\begin{tabular}{|c|c|c|c|c|c|c|c|c|c|c|c|c|c|c|c|}
\hline \multirow{2}{*}{ Specimen } & \multicolumn{3}{|c|}{ Test factors } & \multicolumn{12}{|c|}{ Acceleration amplification coefficient at top of the wall } \\
\hline & $A$ & $B$ & C & $0.05 \mathrm{~g}$ & $0.1 \mathrm{~g}$ & $0.15 \mathrm{~g}$ & $0.2 \mathrm{~g}$ & $0.3 \mathrm{~g}$ & $0.4 \mathrm{~g}$ & $0.5 \mathrm{~g}$ & $0.6 \mathrm{~g}$ & $0.7 \mathrm{~g}$ & $0.8 \mathrm{~g}$ & $0.9 \mathrm{~g}$ & $x_{i}$ \\
\hline $\mathrm{W}-1$ & 2 & 1 & 1 & 2.01 & 2.14 & 2.01 & 2.06 & 1.96 & 1.95 & 1.90 & 2.05 & 2.03 & 1.92 & 1.95 & 21.98 \\
\hline $\mathrm{W}-2$ & 1 & 1 & 2 & 2.15 & 2.33 & 2.18 & 2.08 & 2.03 & 1.94 & 1.95 & 2.12 & 2.15 & 1.93 & 1.92 & 22.78 \\
\hline W-3 & 2 & 2 & 2 & 1.84 & 1.89 & 2.04 & 2.03 & 1.82 & 1.84 & 1.88 & 1.81 & 1.77 & 1.70 & 1.63 & 20.25 \\
\hline W-4 & 1 & 2 & 1 & 1.65 & 1.66 & 1.73 & 1.88 & 1.77 & 1.68 & 1.67 & 1.58 & 1.54 & 1.55 & 1.54 & 18.25 \\
\hline I & 44.76 & 42.23 & 43.03 & & & & & & & & & & & & \\
\hline II & 38.50 & 41.03 & 40.23 & & & & & & & & & & & & \\
\hline$K_{1}$ & 22.38 & 21.12 & 21.52 & & & & & & & & & & & & \\
\hline$K_{2}^{1}$ & 19.25 & 20.52 & 20.12 & & & & & & & & & & & & \\
\hline$R^{2}$ & 3.13 & 0.60 & 1.40 & & & & & & & & & & & & \\
\hline
\end{tabular}

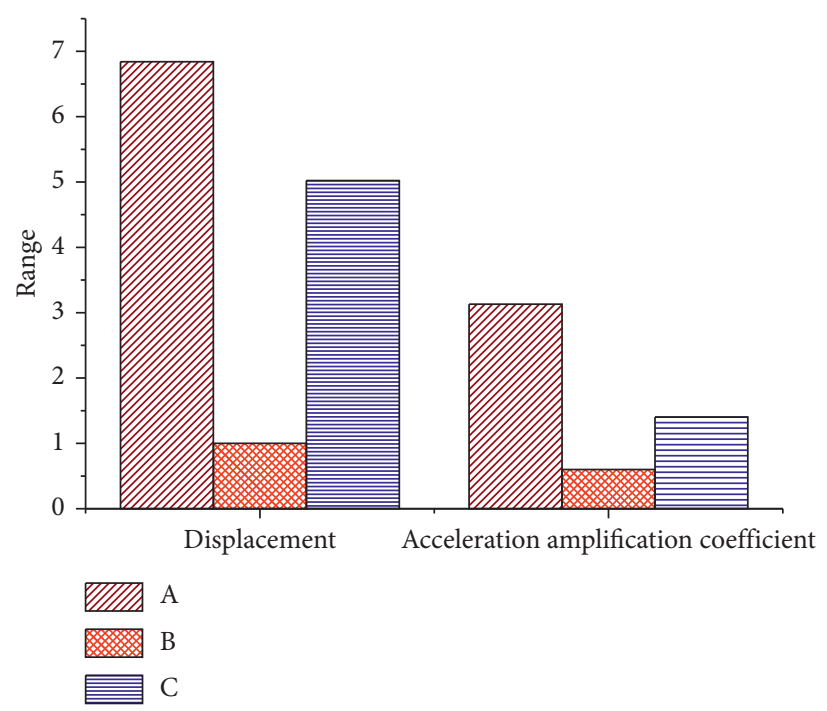

Figure 13: Comparison of range of different test factors.

discussion, some design suggestions can be put forward as follows:

(1) Although the out-of-plane mechanical properties of specimens, whose wall and column is connected only by steel bars, can meet the requirements of the code, considering the force transfer of specimens subjected to in-plane loads, the gaps between beams and columns should be filled with mortar or concrete.
(2) Based on the needs of construction, the connection method between the wall and beam can choose the two methods used in this paper, because both methods can ensure the usage requirements of the wall.

(3) The cast-in-place belt can effectively improve the out-of-plane performance of the specimen. So when designing the structures, the cast-in-place belt should be added to the masonry wall. 


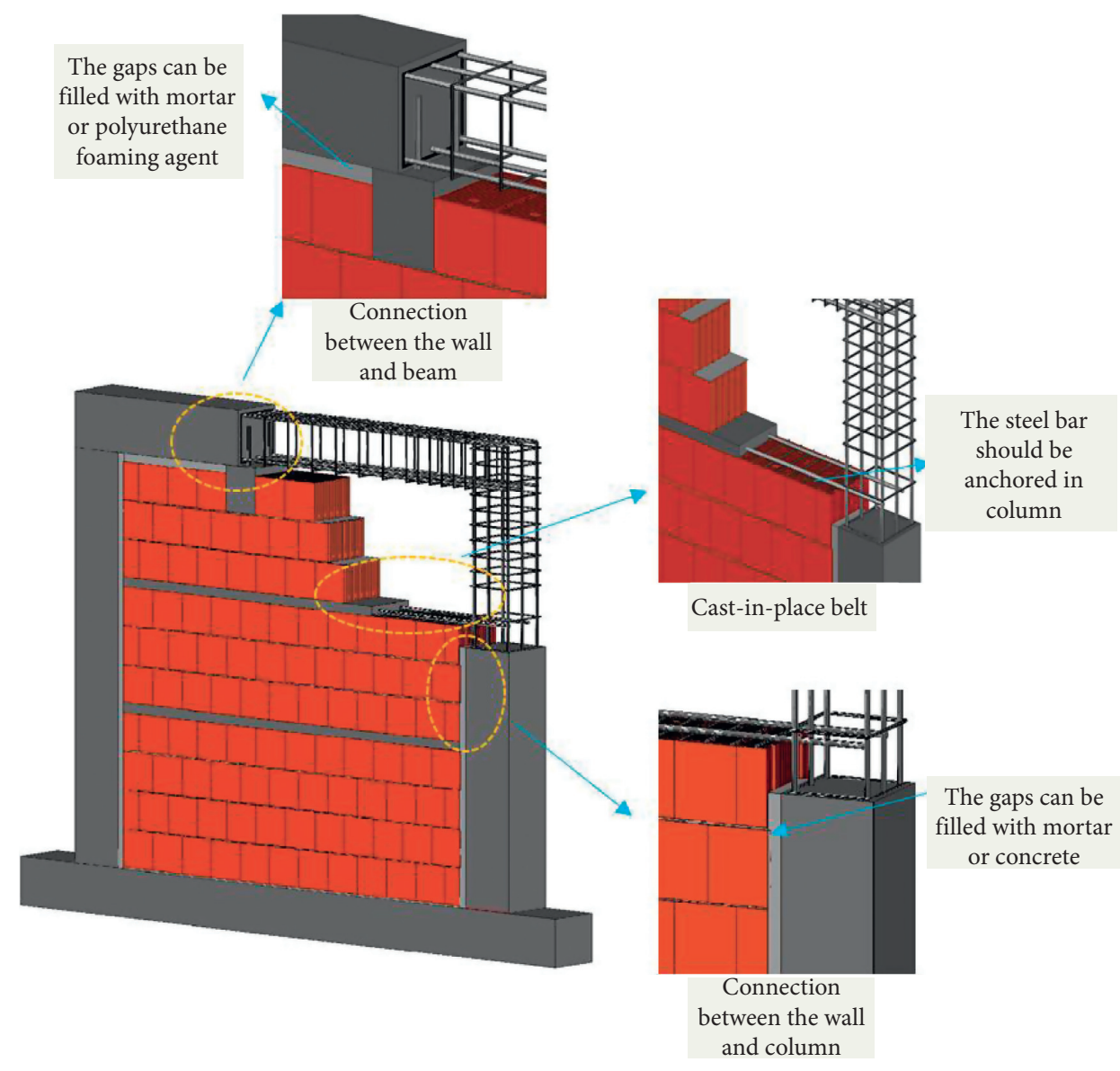

FIGURE 14: Three-dimensional model and its characteristics.

\section{Conclusions}

The results of experimental investigation on the out-of-plane performance of masonry walls, consisting of four shaking table tests on full-scale walls made of shale fired heatinsulation block, were presented and discussed. Several parameters affecting the out-of-plane properties of the infilled frame were tested. The obtained results could be summarized as follows:

(1) The cracks of the wall in the case of out-of-plane failure mainly concentrate on the joints at the bottom of the wall and the bottom of the column.

(2) Compared with flexible connection, rigid connection between walls and beam has stronger arch mechanism, slower frequency decline, and larger out-ofplane stiffness. The frequency changes of rigid or flexible connection between the wall and column are basically the same.

(3) The spacing of cast-in-place belt has the biggest influence on the out-of-plane performance of masonry walls, followed by the connection modes between the wall and beam and column. When the spacing of cast-in-place belt is $750 \mathrm{~mm}$, the wall and frame are rigidly connected and the out-of-plane seismic response is the smallest.

\section{Data Availability}

All data, models, and code generated or used during the study are included within the article.

\section{Conflicts of Interest}

The authors declare that they have no conflicts of interest.

\section{Acknowledgments}

The authors would like to thank the support provided by the Scientific Research Foundation for High-level Talents (XJ17T08), Special Scientific Research Plan of Education Department in Shaanxi Province (18JK1198), the Key Laboratory of Structural Engineering and Earthquake Resistance, Ministry of Education (KLSEER-201901), and National Natural Science Foundation of China (51708037).

\section{References}

[1] GB 50011-2016(Code of China), Code for Seismic Design of Buildings, China Architecture and Building Press, Beijing, China, 2016, in Chinese.

[2] J. Z. Xiao, H. Xie, C. Q. Wang et al., "Statistical analysis on building waste in Wenchuan earthquake-hit area," Journal of 
Sichuan University (Engineering Science Edition), vol. 41, no. 3, pp. 188-194, 2011, in Chinese.

[3] G. Wang, Y. Li, N. Zheng, and J. M. Ingham, "Testing and modelling the in-plane seismic response of clay brick masonry walls with boundary columns made of precast concrete interlocking blocks," Engineering Structures, vol. 131, pp. 513-529, 2017.

[4] A. H. Salmanpour, N. Mojsilović, and J. Schwartz, "Displacement capacity of contemporary unreinforced masonry walls: an experimental study," Engineering Structures, vol. 89, pp. 1-16, 2015.

[5] J. Snoj and M. Dolšek, "Fragility functions for unreinforced masonry walls made from hollow clay units," Engineering Structures, vol. 145, pp. 293-304, 2017.

[6] H. U. Sajid, M. Ashraf, Q. Ali, and S. H. Sajid, "Effects of vertical stresses and flanges on seismic behavior of unreinforced brick masonry," Engineering Structures, vol. 155, pp. 394-409, 2018.

[7] A. Rosti, A. Penna, M. Rota, and G. Magenes, "In-plane cyclic response of low-density AAC URM walls," Materials and Structures, vol. 49, no. 11, pp. 4785-4798, 2016.

[8] L. Cavaleri and F. Di Trapani, "Cyclic response of masonry infilled RC frames: experimental results and simplified modeling," Soil Dynamics and Earthquake Engineering, vol. 65, pp. 224-242, 2014.

[9] P. Morandi, S. Hak, and G. Magenes, "Performance-based interpretation of in-plane cyclic tests on RC frames with strong masonry infills," Engineering Structures, vol. 156, pp. 503-521, 2018.

[10] A. D. Dautaj, Q. Kadiri, and N. Kabashi, "Experimental study on the contribution of masonry infill in the behavior of RC frame under seismic loading," Engineering Structures, vol. 165, pp. 27-37, 2018.

[11] D. Penava, V. Sarhosis, I. Kožar, and I. Guljašs, "Contribution of RC columns and masonry wall to the shear resistance of masonry infilled RC frames containing different in size window and door openings," Engineering Structures, vol. 172, pp. 105-130, 2018.

[12] Q. Peng, X. Zhou, and C. Yang, "Influence of connection and constructional details on masonry-infilled RC frames under cyclic loading," Soil Dynamics and Earthquake Engineering, vol. 108, pp. 96-110, 2018.

[13] S. H. Basha and H. B. Kaushik, "Suitability of fly ash brick masonry as infill in reinforced concrete frames," Materials and Structures, vol. 49, no. 9, pp. 3831-3845, 2016.

[14] Y. Yardim and O. Lalaj, "Shear strengthening of unreinforced masonry wall with different fiber reinforced mortar jacketing," Construction and Building Materials, vol. 102, pp. 149$154,2016$.

[15] M. Shabdin, M. Zargaran, and N. K. A. Attari, "Experimental diagonal tension (shear) test of Un-reinforced masonry (URM) walls strengthened with textile reinforced mortar (TRM)," Construction and Building Materials, vol. 164, pp. 704-715, 2018.

[16] Z. Al-Jaberi, J. J. Myers, and M. A. Elgawady, "Pseudo-static cyclic loading comparison of reinforced masonry walls strengthened with FRCM or NSM FRP," Construction and Building Materials, vol. 167, pp. 482-495, 2018.

[17] A. Leeanansaksiri, P. Panyakapo, and A. Ruangrassamee, "Seismic capacity of masonry infilled RC frame strengthening with expanded metal ferrocement," Engineering Structures, vol. 159, pp. 110-127, 2018.

[18] A. Bustos-García, E. Moreno-Fernández, R. Zavalis et al., "Diagonal compressive tests on masonry wallets coated with mortars reinforced with glass fibers," Materials and Structures, vol. 52, no. 3, pp. 61-13, 2019.

[19] N. Mojsilović, N. Kostić, and J. Schwartz, "Modelling of the behaviour of seismically strengthened masonry walls subjected to cyclic in-plane shear," Engineering Structures, vol. 56, pp. 1117-1129, 2013.

[20] D. Addessi, A. Mastrandrea, and E. Sacco, "An equilibrated macro-element for nonlinear analysis of masonry structures," Engineering Structures, vol. 70, pp. 82-93, 2014.

[21] B. Pantò, F. Cannizzaro, S. Caddemi, and I. Caliò, "3D macroelement modelling approach for seismic assessment of historical masonry churches," Advances in Engineering Software, vol. 97, pp. 40-59, 2016.

[22] A. A. Mobarake, M. Khanmohammadi, and S. R. Mirghaderi, "A new discrete macro-element in an analytical platform for seismic assessment of unreinforced masonry buildings," Engineering Structures, vol. 152, pp. 381-396, 2017.

[23] C. Casapulla, A. Maione, L. U. Argiento, and E. Speranza, "Corner failure in masonry buildings: an updated macromodeling approach with frictional resistances," European Journal of Mechanics-A/Solids, vol. 70, pp. 213-225, 2018.

[24] F. A. Kariou, S. P. Triantafyllou, D. A. Bournas, and L. N. Koutas, "Out-of-plane response of masonry walls strengthened using textile-mortar system," Construction and Building Materials, vol. 165, pp. 769-781, 2018.

[25] Ö. Anil, M. Tatayoğlu, and M. Demirhan, "Out-of-plane behavior of unreinforced masonry brick walls strengthened with CFRP strips," Construction and Building Materials, vol. 35, pp. 614-624, 2012.

[26] H. Sokairge, A. Rashad, and H. Elshafie, "Behavior of posttensioned dry-stack interlocking masonry walls under out of plane loading," Construction and Building Materials, vol. 133, pp. 348-357, 2017.

[27] C. Shermi and R. N. Dubey, "Study on out-of-plane behaviour of unreinforced masonry strengthened with welded wire mesh and mortar," Construction and Building Materials, vol. 143, pp. 104-120, 2017.

[28] R. S. Nezhad, M. Z. Kabir, and M. Banazadeh, "Shaking table test of fibre reinforced masonry walls under out-of-plane loading," Construction and Building Materials, vol. 120, pp. 89-103, 2016.

[29] V. P. Paton-Cole, E. F. Gad, C. Clifton, N. T. K. Lam, C. Davies, and S. Hicks, "Out-of-plane performance of a brick veneer steel-framed house subjected to seismic loads," Construction and Building Materials, vol. 28, no. 1, pp. 779-790, 2012.

[30] F. Graziotti, U. Tomassetti, S. Sharma, L. Grottoli, and G. Magenes, "Experimental response of URM single leaf and cavity walls in out-of-plane two-way bending generated by seismic excitation," Construction and Building Materials, vol. 195, pp. 650-670, 2019.

[31] J. Wu, G.-L. Bai, H.-Y. Zhao, and X. Li, "Mechanical and thermal tests of an innovative environment-friendly hollow block as self-insulation wall materials," Construction and Building Materials, vol. 93, pp. 342-349, 2015.

[32] E. L. McDowell, K. E. Mckee, and E. Sevin, "Arching action theory of masonry walls," Journal of the Structural Division, vol. 82, no. 2, pp. 915-918, 1956.

[33] J. C. Tao and J. M. Wu, "New study on determining the weight of index in synthetic weighted mark method," Systems Engineering Theory and Practice, vol. 21, no. 8, pp. 43-48, 2001, in Chinese. 